УДК 378.14:004.4:81’25

\author{
Oksana B. Bihych \\ Doctor of Pedagogical Sciences, Department of Foreign Languages Teaching Methodology \\ and Information and Communication Technologies, Professor \\ Kyiv National Linguistic University, Kyiv, Ukraine \\ ORCID ID 0000-0002-7997-8487 \\ bkbpearl@gmail.com \\ Valentyna V. Strilets \\ PhD of Pedagogical Sciences, Department of Foreign Philology and Translation, Associate Professor \\ National University of Life and Environmental Sciences of Ukraine, Kyiv, Ukraine \\ ORCID ID 0000-0003-0806-0289 \\ vvctrilets@gmail.com
}

\title{
POTENTIAL FOR THE USE OF ICT IN TEACHING SCIENTIFIC AND TECHNICAL TRANSLATION
}

\begin{abstract}
The article analyzes the features of both general-purpose and translation ICT tools, which can be applied at different stages of scientific and technical translation and, accordingly, in the process of would-be translators' professional training. General-purpose ICT tools include a Word processor as a means of the target text formatting and finalizing; search engines necessary for widening background, subject-matter and linguistic knowledge at the information-reference and terminology search stages; means of electronic communication, in particular email, providing interaction among the translation project participants. The paper focuses on advantages and disadvantages of translation ICT tools: translation databases (Reverso context); electronic dictionaries (ABBYY Lingvo, multitran) necessary for improving and expanding would-be translators' vocabulary; electronic text corpora as sources of authentic linguistic materials, machine translation systems (Google Translate) and CAT tools (Trados, SmartCAT) capable of accelerating target text drafting. In the context of machine translation analysis, the necessity to determine the indicators of machine translatability and to carry out source text pre-editing based on controlled language rules and target text post-editing is emphasized. It is pointed out that CAT tools can increase translators' performance, provide terminology consistency and enable translation project management; at the same time, their application requires developing special skills. A number of issues that need further research are outlined: concretizing the translator training stages appropriate for introducing specific ICT tools; the ratio of the training time allotted for pen and paper translation and ICT-based one; the expediency of applying machine translation systems, in particular Google Translate, in each particular case.
\end{abstract}

Keywords: scientific and technical translation; ICT; ICT competence; general-purpose ICT tools; translation ICT tools; electronic dictionary; text corpora; machine translation; CAT tools.

\section{INTRODUCTION}

Statement of the problem. Scientific and technical translation is rapidly moving to the online environment and becoming more and more automated, and translators' proficiency in Information and Communication Technology (ICT) (computer assisted translation (CAT) tools, machine translation systems, electronic dictionaries, search engines, means of electronic communication) is the labour market's requirement. Accordingly, translators' training at higher educational institutions must be aimed at forming their ICT competence, as an integral part of professional scientific and technical translation competence, which includes their readiness and ability to apply ICT tools when translating scientific and technical texts, as well as appropriate knowledge, skills, sub-skills, "value-based orientations, information-focused outlook and personal qualities" [1, p. 8]. It is obvious that ICTs should be integrated in the teaching-learning process to create a contemporary information and communication 
environment for future scientific and technical translators, which, in its turn, requires analyzing the capabilities of ICTs as supportive means of translator's activity at different stages.

Analysis of recent research and publications. Scholars have studied different aspects of applying ICT in teaching translation to both future philologists and students majoring in non-linguistic specialties, namely those undertaking the program "Translator in the professional communication field". The didactic principles have been formed by Ye. V. Ivanov [2], who has methodologically substantiated ICT application in translators' professional training; O. V. Grebenshchikova [3], who has proved the necessity of complex ICT application for involving students in the quasi-professional activity; O. O. Matsiuk [4], who has outlined pedagogical conditions for forming future translators' professional competence by means of ICT (Internet, email, translation software, training software, media portals, electronic encyclopedia and dictionaries). Yu. Z. Kolos [1] has suggested a definition of future translators' information and communication competence and determined its content; N. G. Iniutin [5, p. 20] has concretized its components (lingua-technological, communicationtechnological, information and research, information and management, production and technological, technical and technological) and described a translator's workplace, which includes hardware, appropriate software, local electronic resources and Internet resources; Yu. V. Troitskaya [6] has studied possibilities of applying ICT, in particular multimedia means, through the lens of forming future translators' professional mobility; Ye. V. Ozhegova [7] has elaborated the methodology of forming their lingua-information independence by means of a course-book, a distance course and an electronic network community. A. V. Yankovets [8] has researched future military translators' training with the help of ICT, focusing on developing their English communicative rather than translation competence; N. O. Makoyed [9] has substantiated pedagogical conditions for forming in future engineers translation for specific purposes skills by means of computer technologies, however, pieces of software mentioned by the author are currently outdated. In the context of training students of non-linguistic specialties undertaking the program "Translator in the professional communication field", D. A. Alferova [10] has suggested the typology of ICT which can be used in translator's activity (general-purpose software and translation software), has revealed the peculiar features of using the Internet, and has shown ICT capabilities for handling typical translation tasks; O. O. Artemenko [11, p. 21] has emphasized the importance of involving students in Internet-based synchronous and asynchronous interaction with professional translators and potential employers. Ye. A. Kozlenkova [12] has determined methodological bases of developing a distance course for teaching translation. Today a number of scholars are trying to gain a deeper insight into the problem of CAT tools and machine translation application. M. C. Odacioglu and S. Kokturk [13] have researched the impact of translation memory, terminology databases, translation management tools, and electronic text corpora on future translators' professional training. M. Yamada [14] has conducted an empirical study of the influence of translation memory and machine translation on the translation process, S. Doherty [15] has analyzed their effect on both the process and result. J. Lee and P. Liao [16] have compared human translation with machine translation followed by post-editing. A. Pym [17, p. 494-496] has characterized three groups of skills a translator needs at the current stage of CAT development: learning to learn, learning to trust and mistrust data, and learning to revise translations as texts. Linguists have examined the issue of scientific and technical texts' machine translatability. O. I. Babina [18] has classified formal machine translatability indicators for Russian scientific and technical texts. Considering multilingual text communication in the light of contemporary linguistic technologies (on the material of technical documentation), A. L. Mishchenko [19] has analyzed the concept of controlled languages, in particular, their application for machine translation of scientific and technical 
texts, and researched virtual systems suitable for translators' professional activity, in particular, controlled language check systems, translation memory and machine translation. In spite of the researchers' keen interest in the issue of ICT application for translation purposes, their studies lack a comprehensive analysis of ICT capabilities for supporting scientific and technical translator's work.

The purpose of the article is to analyze the features of contemporary ICTs, which are appropriate for applying at different stages of teaching scientific and technical translation.

\section{FINDINGS}

Scientific and technical translation implies faithful conveying of scientific and technical information from one language into another for providing cross-cultural communication in the sphere of science and technology. Today professional scientific and technical translators are required to use ICTs effectively throughout the entire technological chain: receiving a source text (either in printed or digital form), doing preliminary study of the material, clarifying problematic issues (terms, abbreviations, proper names etc.) with a customer and / or experts in a particular field, conducting information-reference and terminology search, negotiating the terminology with other members of the translation project, creating a draft version of the target text, editing, assessing quality, submitting the target text to the customer in the appropriate form. In this article, we are going to consider the capabilities of both generalpurpose and translation ICT tools, which are appropriate for applying at different stages of teaching scientific and technical translation.

General-purpose ICT tools, used by translators in their professional activity, include a Word processor, means of electronic communication (email, chat, forum, social networks), and search engines.

In most cases, an end product (a target text) is created with the help of a word processor. Microsoft Word allows a translator to format the target text according to the customer's requirements; check spelling, grammar and syntax; see the word's definition and its synonyms; determine the text's length (number of words or characters), as well as to perform different manipulations (highlight, copy, paste etc.).

Scientific and technical translators' professional activity is of interactive nature as it implies discussing the translation assignment's terms with an employer / customer; clarifying subject-matter issues with experts in a particular field; communicating with the translation project team members acting as a translator, editor, or translation project manager; sharing experience with professional translators. It requires using means of electronic communication, primarily, email - a technology and service for sending and receiving electronic messages between computer network users. Its advantages are the possibility to send files of different formats, high speed of message transmission and user-friendliness. In translation practice, email is an indispensable means enabling a translator to communicate with a customer / source text author (sometimes these roles are performed by one person), experts in a particular field and colleagues. Via this service, a translator receives a translation brief and a source text in any format (Word, PDF, Excel, Power Point) and sends a target text to a customer.

O. O Artemenko [11, p. 15] suggests organizing electronic communication between university instructors and students, as well as involving students in real professional communication with experienced translators and potential employers through chats and forums of professional translation communities to stimulate their professional development and increase social adaptation.

Both practicing and would-be translators turn to search engines, in particular Google, in the information-reference and terminology search phases for solving a number of problems: clarifying abbreviations, correctness of proper names (anthroponyms, toponyms, ergonyms 
etc.) and collocations; gaining background and subject-matter knowledge through searching, selecting and processing information from Internet resources (databases, sites of professional communities and companies, etc.). Resources containing video information about specific technologies, mechanisms, materials, etc. are especially useful for future translators of scientific and technical texts.

Translation ICT tools comprise translation databases, electronic dictionaries, electronic text corpora and concordances, machine translation systems, and CAT tools.

Reverso Context is an online resource, which, thanks to its simple but powerful search engine, as well as large and varied parallel text corpora, provides users with accurate and prompt translation of words and phrases and demonstrates their usage in a variety of contexts, including specialized ones. Registered users get access to the advanced features allowing them to store the search history and selected examples, enter their own translation example of a certain word or phrase, and inform the Reverso Context team about the errors found. The system is being constantly improved by its developers, who take into account users' comments. Reverso Context will be useful to students at the terminology search phase, allowing them to see the term's usage in parallel text extracts. The disadvantage of this system is the lack of English-Ukrainian and Ukrainian-English correspondences, as well as exposure to the penetration of poor or unedited translations, which requires students to be critical of its content.

Among electronic dictionaries, practicing translators distinguish, first of all, Lingvo, which operates in off-line mode, and on-line dictionary multitran.

ABBYY Lingvo is a computer program and a family of electronic dictionaries developed by ABBYY. Product "ABBYY Lingvo x6 English. Professional version” is an English-Russian and Russian-English dictionary, which includes general purpose sections, thesauruses and 46 thematic dictionaries covering various spheres of activity: economics, banking, accounting, medicine, law, sports, computer technology and programming, telecommunications, mechanical engineering and automation of production, construction and architecture, oil and gas industry, chemistry, physics and many others. The product contains an English grammar course from Oxford University Press and ABBYY Tutor application for learning vocabulary. One can get an instant translation by hovering over the word of the website, image, movie subtitles or PDF file. The new version has advanced features to improve and expand user's vocabulary: listening to the word's pronunciation, viewing its phonetic script, prompt adding words to ABBYY Tutor, setting the exercise schedule. This dictionary will help students to find equivalents of terms, in particular those belonging to a certain field, at the terminology search phase, as well as provide support in their performing different vocabulary-based assignments during independent work.

Multitran is a constantly updated multilingual online dictionary. Its English-RussianEnglish section (the Ukrainian one is lacking) contains over 4 million entries. A huge database is both an advantage and a drawback of this dictionary, which can offer up to 100 word matches, complicating the equivalent selection task for a novice translator while being a great support for a professional one. In addition, the dictionary sometimes offers a very narrow term meaning suitable for a limited context. Each registered user can add their own entry, as well as inform the system of errors. In spite of being useful, these features carry a risk of mistake penetration. The dictionary is a valuable tool for both practicing and would-be scientific and technical translators, as it contains equivalents of general scientific and general technical terms, as well as those belonging to a particular field (oil and gas, mining, construction, mechanical engineering, information technology, architecture, etc.).

According to some researchers [20], [21], [22], monolingual resources are even more important for a translator than bilingual ones. Google Translate system, which will be discussed below, contains additional features (a lexical unit definition, the illustration of its usage in the 
sentence, a list of synonyms), offering a would-be translator a better understanding of how the native speakers define and use a word and what kind of associations they get from it.

Text corpora are enormous arrays of texts in a foreign language, arranged and marked for quick retrieval of information interesting to the user [23, p.89]. The most common types of corpora used to different extents by practicing translators, translator trainers and would-be translators are parallel text corpus and comparable one, the former being bilingual while the latter comprising monolingual texts. They are typically supplemented with concordances programs allowing for carrying out search within the corpus.

Scholars characterize electronic text corpora as a valuable resource of authentic linguistic materials exposing collocations as well as genre and discourse characteristics. L. Bowker [20] highlights their role for retrieving idiomatic expressions. N. Kubler's [21, p. 41] experiment aimed at examining the combination of various types of corpora and the Web in translation for specific purposes training has proved that using comparable corpora helps to overcome problems of "artificiality" in parallel corpora, and general language corpora are necessary to test the degree of specialization of a term. S. Doherty [15, p. 955] points out that corpus-based approaches allow translators to avoid subjectivity and ambiguity by providing authentic texts "that can be used by translators (and evaluators) to justify and verify choices in the translation process and in assessing the severity and impact of translation errors". According to S. Frerot [22], electronic text corpora and corpus technologies are appropriate for applying in academic environment both by translator trainers when preparing teaching materials and would-be translators during their independent work, moreover the latter can create their own (Do-It-Yourself) corpora of certain genres or fields. In the context of teaching scientific and technical translation these can be instruction manuals, specifications, patents, academic articles, abstracts, etc. related to oil and gas, mining, construction, mechanical engineering, information technology, architecture or other fields specified by the syllabus. O. O. Artemenko [11, p. 9] suggests using didactic materials, created in the source language, and their translations, performed by professional translators, for facilitating the process of forming students' transformation competence based on the comparative analysis principle, which correlates with the idea of parallel text corpora.

Machine translation is the process of translating written texts from one language into another using special software. This tool is the most suitable for handling scientific and technical texts: instruction manuals, specifications, technical support documentation etc. The principal disadvantage of machine translation systems is their low sensitivity to the context, semantics of lexical units and complex syntactic structures. Therefore, some scholars suggest elaborating and applying a set of criteria for determining translatability of a particular text. Thus, O. I. Babina has worked out a classification of formal indicators determining machine translatability of Russian scientific and technical texts $[18, \mathrm{p}$. 5]. These indicators make it possible to formalize and automate the evaluation of the text "suitability" for machine translation: the presence of a very large number of indicators implies the need for pre-editing the source text or refusal to use machine translation [18, p. 12]. In this regard, A. L. Mishchenko has summarized 10 basic rules of controlled languages, which are specific to a particular language, in order to avoid ambiguous interpretation of individual segments of the text [19, pp. 302-305]. Compliance with these rules will help a translator to pre-edit the source text.

Today, most practicing translators opt for Google Translate machine translation system due to its availability, regular database updating and continuous improvement. Based on the statistical principle, it automatically translates words, sentences and whole texts from one language into another. It has the same disadvantages as other machine translation tools. In academic literature, there are a number of studies aimed at determining the appropriateness of Google Translate application. J. Lee and P. Liao, who offered 140 students to translate a cell phone user guide with a pen and paper (the first group) and using Google Translate (the 
second group), compared the translation time and accuracy between human translation and machine translation with post-editing, and concluded that students of both experimental groups had spent approximately the same time, however machine translation-based target texts had contained fewer errors and students with lower language proficiency level had demonstrated better than usual results [16, pp. 140-142].

Google Translate, like any other machine translation system, may be useful at the stage of creating a draft version of the target text. Its application involves analyzing the source text to determine the indicators of machine translatability and, consequently, the expediency of machine translation use, pre-editing the source text following the controlled language rules, and post-editing the target text. Given the complexity of these operations requiring a high level of bilingual and operational (translation proper) competencies, Google Translate should be introduced in the teaching-learning process not earlier than in the $3^{\text {rd }}$ year of bachelor's programs.

CAT tools differ from machine translation ones in that they provide help to translators at different levels - word, phrase, sentence, passage, and even text - based on an existing database. The core of modern CAT tools is the translation memory technology - software that stores source texts together with corresponding target texts so that these pairs could be used later (in full or in part, with or without modifications) when a translator, dealing with a new translation project, encounters texts with similar linguistic composition. In addition, CAT tools have other useful features: term extraction, concordance searches, alignment (matching source text segments with their translated renditions), word count and match analysis, predictive typing, spell check, conversion of files, project management and quality assurance facilities.

CAT systems were improved in parallel with the development of ICTs initially as software products for use on one computer (Trados), and more recently as cloud-based tools available over the Internet (SmartCAT). Consequently, both an individual translator and a translation project team, comprising translators, editors and managers, can use these systems.

Both professional translators and scholars [13], [15] emphasize that CAT tools increase a translator's productivity, help ensure terminology consistency, and enable the translation project management. It should be noted that their multi-functionality allows for supporting a translator's activity at all stages and phases of scientific and technical translation. At the same time, their use requires special skills: to analyze the proposed rendition and, if necessary, to edit it; to edit the target text within the automated system; to negotiate translation solutions with other members of the translation project (translators, editors, managers) etc.

The potential of the general-purpose and translation ICT tools for teaching scientific and technical translation is systematized in Table 1.

Table 1

ICT potential for teaching scientific and technical translation

\begin{tabular}{|c|l|l|l|}
\hline ICT type & \multicolumn{1}{|c|}{ ICT tool } & General description & \multicolumn{1}{c|}{$\begin{array}{c}\text { Potential for teaching scientific and } \\
\text { technical translation }\end{array}$} \\
\hline \multirow{2}{*}{} & Microsoft Word & Text editor & $\begin{array}{l}\text { formatting and finalizing the target text; } \\
\text { checking grammar, spelling, and syntax; } \\
\text { finding the word's definition and its } \\
\text { synonyms; } \\
\text { determining the text's length }\end{array}$ \\
\cline { 2 - 4 } & Email & $\begin{array}{l}\text { Means of electronic } \\
\text { communication }\end{array}$ & $\begin{array}{l}\text { communicating with a teacher, other } \\
\text { students, a customer, a source text author, } \\
\text { experts in a particular field and practicing } \\
\text { translators; } \\
\text { receiving a translation brief and a source text } \\
\text { in any format and sending a target text to a } \\
\text { customer }\end{array}$ \\
\hline
\end{tabular}




\begin{tabular}{|c|c|c|c|}
\hline & Chat, forum & $\begin{array}{l}\text { Means of electronic } \\
\text { communication }\end{array}$ & $\begin{array}{l}\text { communicating with a teacher, other } \\
\text { students, a customer, a source text author, } \\
\text { experts in a particular field and practicing } \\
\text { translators; } \\
\text { social adaptation }\end{array}$ \\
\hline & Google & Search engine & $\begin{array}{l}\text { clarifying abbreviations, correctness of } \\
\text { proper names and collocations; } \\
\text { gaining background and subject-matter } \\
\text { knowledge from Internet resources } \\
\text { (databases, sites of professional } \\
\text { communities and companies, etc.) }\end{array}$ \\
\hline \multirow{7}{*}{ 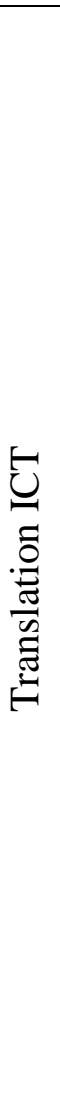 } & Reverso Context & Translation database & $\begin{array}{l}\text { translating words and phrases presented in } \\
\text { different specialized contexts }\end{array}$ \\
\hline & ABBYY Lingvo & $\begin{array}{l}\text { Electronic } \quad \text { off-line } \\
\text { dictionary }\end{array}$ & $\begin{array}{l}\text { finding equivalents of general scientific, } \\
\text { general technical and specialized terms at } \\
\text { the terminology search phase }\end{array}$ \\
\hline & Multitran & $\begin{array}{l}\text { Electronic on-line } \\
\text { dictionary }\end{array}$ & $\begin{array}{l}\text { finding equivalents of general scientific, } \\
\text { general technical and specialized terms at } \\
\text { the terminology search phase }\end{array}$ \\
\hline & $\begin{array}{lr}\begin{array}{l}\text { Parallel } \\
\text { comparable }\end{array} & \text { and } \\
\text { corpora } & \end{array}$ & Electronic text corpora & $\begin{array}{l}\text { accessing authentic specialized texts for } \\
\text { exploring genre characteristics and } \\
\text { specialized term collocations; } \\
\text { testing the degree of terms' specialization } \\
\text { and justifying their choice }\end{array}$ \\
\hline & Concordance & $\begin{array}{l}\text { Program for carrying } \\
\text { out search within the } \\
\text { corpus }\end{array}$ & $\begin{array}{l}\text { instant search for words and phrases in a } \\
\text { great number of authentic texts of a } \\
\text { particular field or genre }\end{array}$ \\
\hline & Google Translate & $\begin{array}{l}\text { Machine translation } \\
\text { system }\end{array}$ & $\begin{array}{l}\text { translating promptly specialized texts at the } \\
\text { stage of draft version creation (requires pre- } \\
\text { and post-editing); } \\
\text { providing definitions, usage in the sentence } \\
\text { and synonyms }\end{array}$ \\
\hline & $\begin{array}{l}\text { Trados, } \\
\text { SmartCAT }\end{array}$ & CAT tools & $\begin{array}{l}\text { translating specialized texts at all stages } \\
\text { based on translation memory, term } \\
\text { extraction, concordance searches, alignment, } \\
\text { word count and match analysis, predictive } \\
\text { typing, spell check, project management and } \\
\text { quality assurance facilities }\end{array}$ \\
\hline
\end{tabular}

\section{CONCLUSIONS AND PROSPECTS FOR FURTHER RESEARCH}

The analysis of the ICT features proves that the above-mentioned tools can be used both for automating routine translation operations (for example, formatting the target text) and for solving translation problems that require a creative approach (searching for and selecting an appropriate lexical equivalent suitable for a particular context, producing the target text in accordance with certain genre peculiarities etc.). They are able to facilitate and accelerate the workflow of scientific and technical translation at different stages (first of all, at the stages of terminology search and target text production), to ensure terminology consistency, as well as the interaction among all translation project members. Undoubtedly, these tools should be involved in the process of translator training, so that would-be translators could acquire necessary knowledge, develop appropriate skills and sub-skills that make up their ICT competence and are closely related to other competencies. At the same time, the integration of ICTs in teaching scientific and technical translation requires solving a number of issues, in particular, specifying the bachelor's program stage, at which it is reasonable to familiarize students with that or another tool. It is 
evident that junior students are not yet ready (not only in information and technological but in language and personal aspects) for the comprehensive application of the above-mentioned ICT tools. In addition, according to the curricula of higher education institutions, they deal with scientific and technical translation in the $3^{\text {rd }}$ or $4^{\text {th }}$ year. On the other hand, the use of generalpurpose and some translation ICT tools (electronic dictionaries, text corpora) would be appropriate and useful for other types of texts (for example, educational, social and political) in the $1^{\text {st }}$ and $2^{\text {nd }}$ year of studies. Therefore, ICT competence should be formed gradually, with the dosed introduction of both general-purpose and translation ICT tools in such a way that $3^{\text {rd }}$ and $4^{\text {th }}$-year students could perform scientific and technical translation in the quasi-professional information and communications environment. It is also necessary to determine the ratio of the training time allotted for pen and paper translation and ICT-based one; the expediency of applying machine translation systems, in particular Google Translate, in each particular case; as well as to elaborate a subsystem of ICT-based exercises for developing would-be translators' competence in scientific and technical translation. These problems constitute the prospect for further research.

\section{REFERENCES (TRANSLATED AND TRANSLITERATED)}

[1] Yu. Z. Kolos, "Formation of information-technological competences of future translators during their training", PhD Thesis abstract, Kyiv, Ukraine, 2010. (in Ukrainian)

[2] Ye. V. Ivanov, "Scientific and methodological principles of applying telecommunications technologies in translators' professional training ”, PhD Thesis abstract, Kursk, Russia, 2010. (in Russian)

[3] A. V. Grebenshchikova, "Formation of future translators' professional competence by means of information and communications technologies", PhD Thesis abstract, Cheliabinsk, Russia, 2005. (in Russian)

[4] O. O. Matsiuk, "Formation of future translators' professional competence by means of information and communications technologies", PhD Thesis abstract, Khmelnytskyi, Ukraine, 2011. (in Ukrainian)

[5] N. G. Iniutin, "Formation of information-technological competence of future "translator in in the professional communication field", PhD Thesis, Nizhniy Novgorod, Russia, 2006. (in Russian)

[6] Yu. V. Troitskaya, "Formation of translators' professional mobility by means of multimedia tools", PhD Thesis, Samara, Russia, 2017. (in Russian)

[7] Ye. V. Ozhegova, "Methodology of forming lingua-information independence of university students future translators", PhD Thesis abstract, Perm, Russia, 2012. (in Russian)

[8] A. V. Yankovets, "Training future translators by means of information and communication technologies in military higher education institutions", PhD Thesis, Khmelnytskyi, Ukraine, 2005. (in Ukrainian)

[9] N. O. Makoyed, "Formation of future engineers' skills to translate texts for specific purposes by means of computer technologies", PhD Thesis, Odesa, Ukraine, 2002. (in Ukrainian)

[10] D. A. Alferova, "Modular teaching of information technologies-assisted translation of scientific and technical texts", PhD Thesis abstract, Moscow, Russia, 2010. (in Russian)

[11] O. A. Artemenko, "Formation of professional communication translation competence of nonlinguistic students with the use of information and communications technologies", PhD Thesis abstract, Kaluga, Russia, 2009. (in Russian)

[12] Ye. A. Kozlenkova, "Methodological bases of elaborating a distance course for teaching translation within the extended education system (English, nonlinguistic higher educational institution, qualification "Translator in the professional communication field")", PhD Thesis abstract, Moscow, Russia, 2009. (in Russian)

[13] M. C. Odacioglu, and S. Kokturk, "The Effects of Technology on Translation Students in Academic Translation Teaching”, Procedia - Social and Behavioral Sciences, vol. 197, pp. 1085-1094, 25 July 2015. (in English)

[14] M. Yamada, "Revising text: an empirical investigation of revision and the effects of integrating a TM and MT system into the translation process", Doctoral dissertation, Tokyo, Japan, 2012, [Online]. Available: http://apple-eye.com/rikkyo/YAMADA_2011.pdf. (in English)

[15] S. Doherty, "The impact of translation technologies on the process and product of translation", International journal of communication, vol. 10, pp. 947-969, 2016. (in English)

[16] J. Lee, and P. Liao, "A Comparative Study of Human Translation and Machine Translation with Postediting", Compilation and Translation Review, vol. 4(2), pp. 105-149, 2011, [Online]. Available: http://ej.nict.gov.tw/CTR/v04.2/ctr040215.pdf. (in English) 
[17] A. Pym, "Translation skill-sets in a machine-translation age". Meta: journal des traducteurs / Meta: Translators' Journal, vol. 58, no. 3, pp. 487-503, 2013, [Online]. Available: http://id.erudit.org/iderudit/1025047ar. (in English)

[18] O. I. Babina, "Machine translatability of English scientific and technical texts", Bulletin of South Yural State University. Series "Linguistics", vol. 11, no. 3, pp. 5-14, 2014. (in Russian )

[19] A. L. Mishchenko, "Multilingual text communication in the light of contemporary linguistic technologies (on the material of technical documentation)", Doctoral dissertation, Kyiv, Ukraine, 2015. (in Ukrainian)

[20] L. Bowker, "Using Specialized Monolingual Native-Language Corpora as a Translation Resource: a Pilot Study”, Meta, vol. 43, no. 4, pp. 631-651, 1998. (in English)

[21] N. Kübler, "Corpora and LSP translation", Corpora in Translator Education, F. Zanettin, S. Bernardini and D. Stewart, Ed. Manchester: St. Jerom, pp. 25-42, 2003. (in English)

[22] S. Frerot, "Corpora and Corpus Technology for Translation Purposes in Professional and Academic Environments. Major Achievements and New Perspectives", Cadernos de Traducao, vol. 36, no. 1, pp. 36-61, 2016, [Online]. Available: http://www.scielo.br /scielo.php?script=sci_arttext\&pid=S217579682016000500036. (in English)

[23] D. A. Alferova, "The applied program means and training of scientific and technical texts translators", Bulletin of Peoples' Friendship University of Russia. Series Education issues: languages and specialty, no. 3, pp. 87-91, 2008. (in Russian).

Text of the article was accepted by Editorial Team13.01.2019

\title{
МОЖЛИВОСТІ ІНФОРМАЦІЙНО-КОМУНІКАЦІЙНИХ ТЕХНОЛОГІЙ ДЛЯ НАВЧАННЯ ПИСЬМОВОГО НАУКОВО-ТЕХНІЧНОГО ПЕРЕКЛАДУ
}

\author{
Бігич Оксана Борисівна \\ доктор педагогічних наук, професор кафедри методики викладання іноземних мов \\ й інформаційно-комунікаційних технологій \\ Київський національний лінгвістичний університет, м. Київ, Україна \\ ORCID ID 0000-0002-7997-8487 \\ bkbpearl@gmail.com \\ Стрілець Валентина Василівна \\ кандидат педагогічних наук, доцент кафедри іноземної філології і перекладу \\ Національний університет біоресурсів і природокористування України, м. Київ, Україна \\ ORCID ID 0000-0003-0806-0289 \\ vvctrilets@gmail.com
}

Анотація. У статті аналізуються функціональні можливості як універсальних, так i професійних засобів ІКТ, які доцільно використовувати на різних етапах письмового перекладу науково-технічних текстів і, відповідно, у процесі фахової підготовки майбутніх перекладачів. Серед універсальних засобів ІКТ виокремлено текстовий редактор, як засіб оформлення тексту перекладу; пошукові системи, необхідні для розширення фонових, предметних і лінгвістичних знань на етапах інформаційно-довідкового й термінологічного пошуку; засоби електронного спілкування, зокрема електронну пошту, який забезпечує взаємодію учасників перекладацького проєкту. Описано переваги і недоліки професійних засобів ІКТ: перекладацьких баз даних (Reverso context); електронних словників (АВВYY Lingvo, multitran), необхідних для поповнення словникового запасу майбутніх перекладачів; корпусів текстів як джерел автентичної лінгвістичної інформації; систем машинного перекладу (Google Translate) та засобів автоматизованого перекладу (Trados, SmartCAT), здатних прискорити процес створення початкової версії тексту перекладу. У контексті аналізу машинного перекладу наголошено на необхідності визначення маркерів машинної переробки тексту, здійснення передредагування тексту оригіналу згідно 3 правилами контрольованих мов та постредагування тексту перекладу. Зазначено, що засоби автоматизованого перекладу підвищують продуктивність праці перекладача, забезпечують узгодженість термінології, уможливлюють управління перекладацьким проєктом; водночас їх застосування передбачає розвиток у студентів спеціальних умінь. Окреслено ряд питань, які потребують подальших досліджень: конкретизація етапу навчання, на якому доречно впроваджувати той чи інший засіб ІКТ; співвідношення навчального часу, відведеного на 
письмовий переклад із листком і ручкою та за допомогою IКТ; доцільність залучення систем машинного перекладу, зокрема Google Translate, у кожному конкретному випадку.

Ключові слова: науково-технічний переклад; ІКТ; ІКТ-компетентність; універсальні засоби IКТ; професійні засоби ІКТ; електронний словник; корпуси текстів; машинний переклад; засоби автоматизованого перекладу.

\title{
ВОЗМОЖНОСТИ ИНФОРМАЦИОННО-КОММУНИКАЦИОННЫХ ТЕХНОЛОГИЙ ДЛЯ ОБУЧЕНИЯ ПИСЬМЕННОМУ НАУЧНО- ТЕХНИЧЕСКОМУ ПЕРЕВОДУ
}

\author{
Бигич Оксана Борисовна \\ доктор педагогических наук, профессор кафедры методики преподавания иностранных \\ языков и информационно-коммуникационных технологий \\ Киевский национальный лингвистический университет, г. Киев, Украина \\ ORCID ID 0000-0002-7997-8487 \\ bkbpearl@gmail.com

\section{Стрилец Валентина Васильевна} \\ кандидат педагогических наук, доцент кафедры иностранной филологии и перевода \\ Национальный университет биоресурсов и природопользования Украины, г. Киев, Украина \\ ORCID ID 0000-0003-0806-0289 \\ vvctrilets@gmail.com
}

\begin{abstract}
Аннотация. В статье анализируются функциональные возможности как универсальных, так и профессиональных средств ИКТ, которые целесообразно использовать на различных этапах письменного перевода научно-технических текстов и, соответственно, в процессе профессиональной подготовки будущих переводчиков. Среди универсальных средств ИКТ выделено текстовый редактор как средство оформления текста перевода; поисковые системы, необходимые для расширения фоновых, предметных и лингвистических знаний на этапах информационно-справочного и терминологического поиска; средства электронной коммуникации, в частности электронную почту, которая обеспечивает взаимодействие участников переводческого проекта. Описаны преимущества и недостатки профессиональных средств ИКТ: переводческих баз данных (Reverso context); электронных словарей (ABBYY Lingvo, multitran), необходимых для пополнения словарного запаса будущих переводчиков; корпусов текстов как источников аутентичной лингвистической информации; систем машинного перевода (Google Translate) и средств автоматизированного перевода (Trados, SmartCAT), способных ускорить процесс создания начальной версии текста перевода. В контексте анализа машинного перевода подчеркнута необходимость определения маркеров машинной переводимости, осуществления предредактирования текста оригинала согласно с правилами контролированных языков и постредактирования текста перевода. Отмечено, что средства автоматизированного перевода повышают производительность работы переводчика, обеспечивают согласованность терминологии, делают возможным управление переводческим проектом; в то же время, их применение требует развития у студентов специальных умений. Определен ряд вопросов, которые требуют дальнейших исследований: конкретизация этапа обучения, на котором уместно внедрять то или иное средство ИКТ; соотношение учебного времени, отведенного на письменный перевод с листком и ручкой и с помощью ИКТ; целесообразность использования систем машинного перевода, в частности Google Translate, в каждом конкретном случае.
\end{abstract}

Ключевые слова: научно-технический перевод; ИКТ; ИКТ-компетентность; универсальные средства ИКТ; профессиональные средства ИКТ; электронный словарь; корпуса текстов; машинный перевод; средства автоматизированного перевода.

\section{$(\mathrm{cc})$ BY-NC-SA}

This work is licensed under Creative Commons Attribution-NonCommercial-ShareAlike 4.0 International License. 